Saudi Journal of Business and Management Studies Abbreviated Key Title: Saudi J Bus Manag Stud ISSN 2415-6663 (Print) |ISSN 2415-6671 (Online) Scholars Middle East Publishers, Dubai, United Arab Emirates Journal homepage: http://scholarsmepub.com/sjbms/

Original Research Article

\title{
Effect of Supervision on Employee Productivity in the Transport Industry in Benue State, Nigeria
}

\author{
Tsetim, James Tersoo ${ }^{1 *}$, Asue, Timothy Terkimbir ${ }^{1}$, and Asenge, Emmanuel Lubem ${ }^{2}$ \\ ${ }^{1}$ Department of Business Administration, Federal University of Agriculture, Makurdi-Nigeria \\ ${ }^{2}$ Department of Business Management, Benue State University, Makurdi- Nigeria
}

DOI: $10.36348 / \mathrm{sjbms.2019.v04i12.008}$

| Received: 19.12.2019 | Accepted: 26.12.2019 | Published: 30.12.2019

*Corresponding author: Tsetim, James Tersoo

\section{Abstract}

This study examined the effect of supervision on employee productivity in the transport industry in Benue State, Nigeria with focus on Benue Links Nigeria Limited, Makurdi. The study specifically examined the effect of authoritarian supervision, companionable supervision and synergistic supervision on employee productivity in Benue Links Nigeria Limited, Makurdi. Three hypotheses were formulated in line with the objectives. The study used a population of 202 staff of the company and a census sampling technique was adopted for the study. The study adopted a survey research design and questionnaire was employed as the instrument of data collection. Multiple regression analysis was used for data analysis and test of formulated hypotheses using the Statistical Package for Social Sciences (SPSS version 21). Findings of the study revealed that there is significant effect of authoritarian supervision on employee productivity in Benue Links Nigeria Limited, Makurdi. The study also indicated that companionable supervision and synergistic supervision have positive significant effect on employee productivity in Benue Links Nigeria Limited, Makurdi. The study concluded that supervision is indispensable in achieving quality and timely service delivery in the transport sector. It recommended amongst others that employees of Benue Links Nigeria Limited and other transport companies should be intimated of the necessity of supervision so that they avail themselves the benefits of supervision in improving their productivity and supervisors in the road transport industry should not be interested in finding faults of employees but more importantly, dialogue with employees to identify their strengths and weaknesses in order to improve on their professional knowledge, skills and experiences.

Keywords: Supervision, Authoritarian Supervision, Companionable Supervision, Synergistic Supervision, Employee Productivity.

Copyright @ 2019: This is an open-access article distributed under the terms of the Creative Commons Attribution license which permits unrestricted use, distribution, and reproduction in any medium for non-commercial use (NonCommercial, or CC-BY-NC) provided the original author and source are credited.

\section{INTRODUCTION}

Road transport operations transcend national boundaries and play a fundamental role in linking global supply chains and enhancing personal mobility. Transport operations and logistics performance have the power to stimulate national development and economic activities [1]. Accordingly, the sector's resilience in the future lies not only in its environmental efficiency but also in its ability to address decent work challenges. The sector is one in which non-standard forms of employment and outsourcing influence job security and in which liberalization and reform have gone hand in hand with high levels of competition [2]. It is important that productivity of employees is constantly monitored and reviewed for organisations to be abreast with changes and trends in competition and developments [3].Supervision has become important in order to ensure that employees don't deviate or fall short of expectations and in the end, ensure that the organization has a fair share of the market [4]. Various initiatives across different industries worldwide have led to significant changes in the way that organisations operate. These include the introduction of self-managed teams (SMTs), multi-skilling, and increased contractualisation $[8,6]$. The significance of supervision for enhancing the productivity of employee in an organisation cannot be ignored in the 
developmental process of any country. It is generally accepted that structures put in place in every organization must be seen working and to ensure that work is carried out to the desired standard, supervision methods such as monitoring, support and evaluation must come into play.

Supervision is a control mechanism which has the task of correcting the activities of individuals and groups to ensure that their performance is in accordance with plans [7]. Reichelt \& Skjerve [8] averred that supervision has direct effect on staff productivity. Supervisors assign tasks and clear responsibilities of performing those tasks and they in turn expect accuracy and punctuality from assignees (employees). Additionally, supervision gives the right direction to employees under supervision to enable those takes initiative and responsibilities to advance on their own [9]. Supervision seeks to equip individuals with the necessary knowledge, attitudes and skills to make them useful; not only to themselves but their immediate organisation and country. In all countries, supervision and support services have, throughout their long history, become complex and intricate systems, undergoing various changes and reforms, the direction of which is not yet fully clear. The transport industry in Nigeria is not an exception. It is one industry that needs supervision looking at the attitudes of employees in the sector and the poor state of the road network [1]. This places greater responsibilities on the industry players as failure to deliver is not only unacceptable but a real disaster to the nation. Admittedly, plans must be made but in most cases might not be achieved unless activities are monitored, and deviation from plans identified and corrected as soon as they become apparent [2].

Winston and Creamer [10] classified supervision into three basic categories namely; authoritarian supervision, companionable supervision and synergistic supervision. Authoritarian supervision is based on the belief that members require continuous attention because they are often undependable or immature basically, because people will attempt to work as little as possible unless someone monitors them carefully. Companionable supervision is based principally on a friendship-like relationship while synergistic supervision is a cooperative effort between the supervisor and members that allows the effect of the joint effort to be greater than the sum of their individual contributions. These dimensions of supervision affect the productivity of employees in both public and private sector organizations. Productivity is the ratio between input and output and the rate at which employees are able to achieve set goals. Productivity in service organizations is measured regarding quality of service and service timeliness. The relationship between supervisor's behaviour or the style of supervision and employee productivity has gained increased attention recently. The level of supervision influences how organizations cope with increasing competition.
Supervision plays a crucial role in improving productivity by way of improved efficiency and effectiveness and by creating strategic vision of the organization [11]. Performance in every organization is largely centered on labour productivity since human labour is the universal key resource required of any organization [1]. In the words of Mason and Hayes [12], supervision is an effective tool that could be used to promote good results as far as employee productivity is concerned.

Benue Links Nigeria Limited, Makurdi being the market leader in the transport industry in Benue State is expected to enhance productivity of its employees with supervision as a tool to ensure compliance to standards and goals. A critical assessment of the attitude of staff of the company towards work and customers is unimaginable. Customers that regularly patronize the company complain of staff spending longer hours in attending to them. There are also complaints about reckless driving, drink driving, rude attitudes of staff, missing luggage amongst others. Records of action plans, monitoring and follow up reports show that supervision goes on in every unit, but unfortunately the effect does not seem to show in the work life of staff. These negative trends in Benue Links Nigeria Limited, Makurdi have posed a lot of questions that call for investigation. It is based on this backdrop that this study examines the effect of supervision on employee productivity in the road transport industry in Nigeria specific focus on Benue Links Nigeria Limited, Makurdi. The study specifically seeks to: determine the effect of authoritarian supervision on employee productivity in Benue Links Nigeria Limited, Makurdi; ascertain the effect of companionable supervision on employee productivity in Benue Links Nigeria Limited and assess the effect of synergetic supervision on employee productivity in Benue Links Nigeria Limited, Makurdi.

\section{Research Hypotheses}

The study is guided by the following null hypotheses:

$\mathrm{HO}_{1}$ : Authoritarian supervision has no significant effect on employee productivity in Benue Links Nigeria Limited, Makurdi.

$\mathrm{HO}_{2}$ : Companionable supervision has no significant effect on employee productivity in Benue Links Nigeria Limited, Makurdi

$\mathrm{HO}_{3}$ : Synergistic supervision has no significant effect on employee productivity in Benue Links Nigeria Limited, Makurdi

\section{LITERATURE REVIEW}

This sub-section of the study concentrates on examining the concepts that are related to this study. The concepts considered in this study are supervision and employee productivity. 


\section{Concept of Supervision}

The term supervision is derived from the word "Super video" meaning to oversee [13]. It is an interaction between at least two persons for the improvement of an activity. It is also a combination or integration of processes, procedures and conditions that are consciously designed to advance the work effectiveness of individuals and group [13]. Supervision is a way of stimulating, guiding, improving, refreshing, encouraging and overseeing certain group with the hope of seeking their cooperation in order for the supervisors to be successful in their task of supervision [14]. According to Hechanova-Alampay and Beehr [15], to measure the performance of a worker, a supervisor has to observe the worker on the job over a period of time. It is inferred that the supervisor is familiar with the individual with regard to performance and the fact that he has had the opportunity to observe the actual performance for a long time. Ryan [16], states that supervision is an enquiry into practice. It is a compassionate, appreciative inquiry. He further states in supervision we re-write the stories of our own practice, it wakes us up to what we are doing. When we are alive to what we are doing, we wake up to what is, instead of falling asleep in the comfort stories of our clinical routines. Lane and Corrie [17] looked at supervision as a form of experimental learning which implies that supervision is reflection on action or indeed, reflectionin-action to result in reflection for action. It is believed that an effective supervisor can be a business most valuable asset. The well trained supervisor who excels at managing employees can make everyone around him or her more effective and efficient.

Several supervisory skills directly affect employee's development, helping them to achieve their potential while gaining skills that are valuable to the organization. Typically, the performance of each individual should create an impression in the entire organisation. The supervisor is expected to have knowledge in the area of the staff and have to build the relationship. This is the reason for which supervisors should build the respect, trust, and collegiality that increase the interaction abilities of the staff. Both staff and the supervisor should engage in wide variety of activities. Through the help of the guidance and supervision program, the employees are allowed to experiment, practice, and learn through their mistakes. All of the experience that the staff can gather is effective reference or sources for his sole decision making [18].

In this study, supervision is defined as the practice of monitoring the performance of workers or staff, noting the merit and demerits and using befitting and amicable techniques to correct the flaws while still improving on the merits thereby increasing staff productivity and achieving the ultimate goals. Impliedly, when all supervisors guide and develop employees or staff, it will go a long way to improve productivity. Appraising the performance of the staff is the duty of the supervisor to determine the improvement on staff productivity. Appraisals are set in order to supervise the accomplishment of the job, goals, and standards. This can also be done daily, as far as it is responding on the changing needs of the staff and their phases of improvement. The process of supervision can take on one or a combination of styles, and one particular style may not be appropriate for every supervisory situation. It is important that a supervisor is aware of his or her predominate approach to supervision so that the style may be adapted as the situation or the staff member requires.

Winston and Creamer [19] suggested four dimensions of supervision to include authoritarian, laissez faire, companionable and synergetic. This study however dwells on authoritarian, companionable and synergistic supervision.

\section{Authoritarian Supervision}

Authoritarian supervision is based on the belief that members require continuous attention because they are often undependable or immature, basically, because people will attempt to work as little as possible unless someone monitors them carefully [4]. Peck, Lynam and Rosenberg [20] argued that since employees cannot be trusted to fulfill their tasks, the supervisor must check them frequently. The supervisor is ultimately responsible for members' performance. Consequently, close observation is an essential part of the supervisor's responsibilities.

\section{Companionable Supervision}

Companionable supervision is based principally on a friendship-like relationship. In this type of supervision, supervisors seek to be liked and to create harmonious relationships among members; they concentrate on being partners with the staff they supervise and avoid confronting them about poor job performance or mistakes in judgment as long as possible [21].

\section{Synergistic Supervision}

This is a cooperative effort between the supervisor and members that allows the effect of the joint effort to be greater than the sum of their individual contributions [21]. Supervision in this approach has a dual focus: accomplishment of the organization's goal and support of the staff in the accomplishment of their personal and professional development goals. This approach to supervision emphasizes the identification of potential problems early; the supervisor and member then jointly develop strategies to prevent or ameliorate problem situations [22]. This form of supervision is aimed at assisting all employees to enhance their knowledge and skills, which can lead to advancement within the organization and profession [21]. 


\section{Concept of Employee Productivity}

The productivity of an employee represents the various factors such as the functions and roles assigned to them; the organisational structure in which they operate; their workload; and work management [23]. Productivity is an economic measure of efficiency that summarizes and reflects the value of the output created by an individual, organisation, industry or economic system relative to the value of the organisations used to create them [24]. Productivity is in essence a measure a measure of the work efficiency of an individual, work unit or entire organisation. Productivity may be evaluated in terms of the output of an employee in a specific period of time. Typically, the productivity of a given worker is assessed relative to an average for employees doing similar work. According to Chen [19] a successful organization require employees who are willing to do more than their usual job scope and contribute performance that is beyond goal's expectations. Nowadays, most organizations are facing contemporary challenges that require them to put more attention on enhancing employees' productivity [16]. Additionally, organizational policies and daily practices need to interact well to builds prior standard in employees' productivity [16]. This study is in support of this concept in that each individual's work adds up to achieving goals of the organisation. It is therefore crucial for management of Benue Links to set standards for the staff to keep them aligned in their field of work or to adopt appropriate supervision approaches to increase their productivity. Proper supervision therefore increases the quality of service delivery and timeliness of services provided by employees.

\section{Relationship between Supervision and Employee Productivity}

The relationship between supervision and productivity has been viewed and studied by different scholars from different backgrounds [4, 25]. EsiaDonkoh and Ofosu-Dwamena [25], in their study found supervision as having a positive impact on the productivity of employees in terms of developing experience; skills and knowledge. They also argued that supervision help to identify the needs of employees thereby improving their productivity in the organization. Glickman, Gordon and Rose [6] established that through companionable supervision, supervisors get to uncover strengths and weaknesses of employees and encourage them to reflect on their challenges through which solutions are found to overcome them. Chotarea, Girardon and Ventouri [21] in their study asserted that synergistic supervision assists all employees to enhance their knowledge and skills, which can lead to advancement within the organization and profession. Ladany [4] on the other hand found that employees will attempt to work as little as possible unless someone monitors them carefully. This is supported by Peck, Lynam and Rosenberg [20] who found close observation as an essential part of the supervisor's responsibilities as employees cannot be trusted to fulfill their tasks, the supervisor must check on them frequently as he is ultimately responsible for members' performance.

Apenteng [26] stated that supervision cannot be overlooked since it is a major tool for better staff performance giving the right supervisors, right tools and right resources. His study showed that appraisal results are important for counseling sessions since staff expects that they are directed where they fall short. Bouheni [9] in his study in the banking sector concluded that banking supervision has a positive impact on performance of employees. Results from Hoojqan, Gharamani and Safari [27] showed that supervision is effective in improving the performance of employees by strengthening their skills, methods, the degree of participation in the in-service courses, strengthening human relations, reforming and strengthening the evaluation methods and encouraging judicious use of resources. Winston and Creamer [28] stated that supervision affects the overall operational performance in terms of effectiveness, efficiency, profitability, large market share and commitment to achieve stated goals. Apenteng [26] in a study on the effect of supervision on staff performance in the Ga South Municipal Education Directorate concluded that appraisal results are important for counseling sessions since staff expects that they are directed where they fall short. It recommended that for improved performance, supervisors must make staff job satisfaction their top priority.

In support of previous studies, Bouheni [9] carried out a study on the effect of supervision on banking performance and found that banking supervision have significant impact on performance of employees. A study by Esia-Donkoh and OfosuDwamena [25] on the effects of educational supervision on professional development of Public Basic School teachers at Winneba, Ghana indicated that teachers perceived educational supervision have a positive impact on their professional development in terms of developing experience; curriculum, teaching methods and materials; classroom management; characteristics of pupils and assessment. The study however showed no significant difference in the views of male and female teachers of public basic schools at Winneba, in terms of developing their experiences, classroom management, characteristics of the pupils they teach, and assessment techniques. Hoojqan, Gharamani and Safari [27] also argued that educational supervision is effective on improving the performance of guidance school teachers in Marand in the fields of improving teaching methods, the degree of participation in the inservice courses, strengthening human relations, reforming and strengthening the evaluation methods and encouraging the use of teaching aids. 


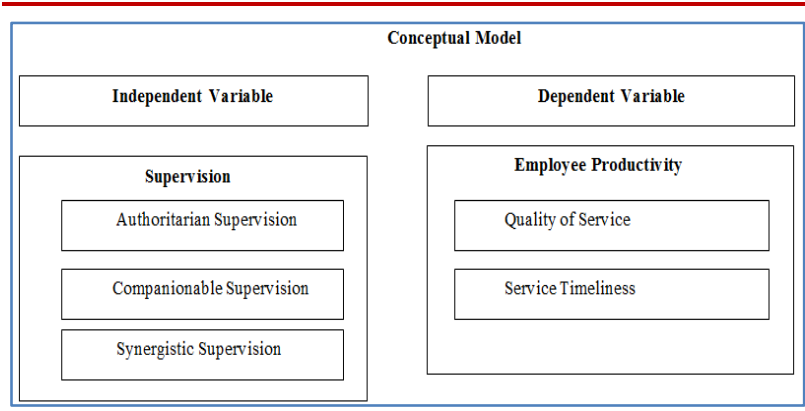

\section{MATERIALS AND METHODS}

This research utilized cross-sectional research design. The use of this method of research design involves the collection of data from a representative sample or population a specific place and time. This was essential for purposes of managing the process of data collection since objectivity was the major concern for this restricted data samples. The population of the study consists of 202 staff of Benue Links Nigeria Limited including 15 management staff, 55 administrative staff and 132 drivers. A census sampling technique was adopted for the study and the entire population was used as the sample size. Questionnaire was used as the instrument for data collection. The instrument was designed on a four-point Likert scale ranging from strongly disagrees to strongly agree with closed-ended questions. The questionnaire was carefully developed by taking into consideration the various key variables and or items necessary for analysis. The instrument was administered to the participants with the assistance of two staff of Benue Links Nigeria Limited, Makurdi. To ensure validity of the instrument, factor analysis was used. The construct validity of each variable was done to measure Exploratory Factor Analysis (EFA) and Confirmatory Factor Analysis (CFA). This was done to ensure consistency in the measurement of items. The result of the Bartlett's test of Sphericity at $1 \%$ level of significance showed that the items were highly significant $(\mathrm{p}<0.001)$. The results of KMO and Bartlett's Test was .789 with Approx. Chi-square= 835.121 and sig $=.000$. For reliability of the instrument, a pilot test was done on $1 / 3$ of the sample size $(0.333 \mathrm{x}$ $202=67$ ). This was necessary to ensure consistency of items of the questionnaire. The result of the pilot test indicated that Cronbach's Alpha for each of the constructs was greater than .70 and were considered reliable and used in this study. Multiple regression analysis was used to measure the effect of supervision on employee productivity and test of formulated hypotheses at 0.05 level of significance with the aid of the Statistical Package for Social Sciences (SPSS 21).

\section{RESULTS AND DISCUSSION}

This sub-section is discussed under model summary, analysis of variance and regression coefficients.

Table-1: Model Summary

\begin{tabular}{|l|l|l|l|l|}
\hline $\mathbf{R}$ & R-Square & $\begin{array}{r}\text { Adjusted R } \\
\text { Square }\end{array}$ & $\begin{array}{c}\text { Std. Error of } \\
\text { the Estimate }\end{array}$ & Durbin-Watson \\
\hline $.701^{\mathrm{a}}$ & .492 & .479 & .39040 & 1.021 \\
\hline
\end{tabular}

Source: Field Survey, 2019.

a. Predictors (Constant), Synergistic supervision, companionable supervision, authoritarian supervision

b. Dependent Variable: Employee Productivity

The result from Table 1 shows that coefficient of determination ( $\mathrm{R}$ square) explains the variation in the dependent variable due to changes in the independent variable. The $\mathrm{R}$ square value of 0.492 indicates that there was $49.2 \%$ variation in employee productivity due to changes in synergistic supervision, companionable supervision and authoritarian supervision at 95\% confidence interval. Also, the value of R (0.701) from Table 1 shows that there was a strong positive relationship between the study variables.

Table-2: Analysis of Variance (ANOVA)

\begin{tabular}{|l|l|l|l|l|l|}
\hline & $\begin{array}{l}\text { Sum of } \\
\text { Squares }\end{array}$ & df & Mean Square & F & Sig. \\
\hline Regression & 17.846 & 3 & 5.949 & 39.029 & $.000^{\mathrm{b}}$ \\
\hline Residual & 18.442 & 198 & .152 & & \\
\hline Total & 36.288 & 201 & & & \\
\hline \multicolumn{7}{|c|}{ Source: Field Survey, 2019. } \\
\hline
\end{tabular}

a. Dependent Variable: Employee Productivity

b. Predictors (Constant), Synergistic supervision, companionable supervision, authoritarian supervision

The result of the analysis of variance as presented in Table 2 indicates that the processed data, which is the population parameters, had a significance level of 0.000 which is less than the significance value at $5 \%(0.05)$. This implies that synergistic, companionable and authoritarian supervisions have significant effect on productivity of employees in Benue Links Nigeria Limited, Makurdi. 
Tsetim, James Tersoo et al; Saudi J Bus Manag Stud, Dec., 2019; 4(12): 912-918

Table-3: Regression Coefficients

\begin{tabular}{|l|l|l|l|l|l|}
\hline \multicolumn{2}{|c|}{ Unstandardized Coefficients } & \multicolumn{3}{l|}{ Standardized Coefficients } \\
\hline & $\mathrm{B}$ & Std. Error & Beta & t & Sig. \\
\hline (Constant) & 1.178 & .161 & - & 7.325 & .000 \\
\hline Authoritarian & .247 & .065 & .332 & 3.820 & .000 \\
\hline Companionable & .252 & .041 & .403 & 6.172 & .000 \\
\hline Synergistic & .295 & .073 & .350 & 4.051 & .000 \\
\hline
\end{tabular}

a. Dependent Variable: Employee productivity

Source: Field Survey, 2019.

From the data in the Table 3, the established regression equation is presented thus: Employee Productivity $=1.178+0.247$ (Authoritarian Supervision) +-0.252 (Companionable Supervision) + 0.295 (Synergistic Supervision).

The regression equation above revealed that holding authoritarian, companionable and synergistic supervision to a constant zero, productivity would be 1.178 , a unit increase in authoritarian supervision would affect employee productivity by $24.7 \%$, a unit increase in companionable supervision would affect employee productivity by $25.2 \%$ and a unit increase in synergetic supervision would affect employee productivity by 29.2 $\%$. The study also found that the p-values of authoritarian, companionable and synergistic supervision $(.000, .000, .000)$ respectively were less than 0.05 which is an indication that all the independent variables significantly affect productivity of employees in Benue Links Nigeria Limited, Makurdi. Furthermore, the result of the analysis shows that synergistic supervision has more significant effect on employee productivity in Benue Links Nigeria Limited, Makurdi. The three hypotheses formulated for the study were thus rejected and alternate hypotheses accepted.

Analysis of the data collected from the respondents revealed that authoritarian supervision has significant effect on employee productivity in Benue Links Nigeria Limited, Makurdi. This result corroborates previous study by Ladany [4] who found that employees will attempt to work as little as possible unless someone monitors them carefully. The result is also supported by Peck, Lynam and Rosenberg [20] who found that close observation is an essential part of the supervisor's responsibilities as employees cannot be trusted to fulfill their tasks, the supervisor must check on them frequently as he is ultimately responsible for members' performance. Findings of the study also indicated that companionable supervision has significant effect on employee productivity in Benue Links Nigeria Limited, Makurdi. This result is in agreement with Glickman, Gordon and Rose [6] who asserts that through companionable supervision, supervisors get to uncover strengths and weaknesses of employees and encourage them to reflect on their challenges through which solutions are found to overcome them. Finally, the study revealed that synergistic supervision has significant effect on employee productivity in Benue Links Nigeria Limited,
Makurdi. This result is in line with Chotarea, Girardon and Ventouri [21] who found that synergistic supervision assists all members to enhance their knowledge and skills, which can lead to advancement within the organization and profession.

\section{CONCLUSION}

This study examines the effect of supervision on employee productivity in the transport industry in Benue State, Nigeria with particular focus on Benue Links Nigeria Limited, Makurdi. The study indicated that authoritarian supervision, companionable supervision and synergistic supervision positively affect the productivity of employees. It concluded that supervision has a positive effect on employee productivity and an increase in supervision will bring about a proportionate increase in the productivity of employees in the road transport sector in Benue State, Nigeria. The implication of this to management is that if work environment is conducive to guarantee effective supervision, productivity of employees will be enhanced. But in the event where the employees are not supervised, employee productivity will be reduced and the long run effect will be a negative effect on overall organizational performance. Based on the findings, the study recommended amongst others that employees of the transport industry should be intimated of the necessity of supervision so that they do not see it as witch hunting but uses it as an approach to improve their productivity. Supervisors in the road transport industry in Nigeria should not be interested in finding faults in employees but more importantly, dialogue with employees to identify their strengths and weaknesses in order to improve on their professional knowledge, skills and experiences. Also, management of transport companies in Nigeria should make work environment conducive so as to guarantee organizational coexistence which facilitates employees' responsiveness to supervision thereby improving their productivity.

\section{REFERENCES}

1. Efobi, K., \& Anierobi, C. (2014). Mass Transportation System in Nigeria: Strategies for Effective Maintenance Culture in Public Sector Operations of Enugu State,Journal of Energy Technologies and Policy, 4(1), 14-18

2. Adeyinka, A.M. (2013). Assessment of the Quality of Urban Transport Services in Nigeria, Academic Journal of Interdisciplinary Studies, 2(1), 18-26 
3. Sears, S. (2003). Ohio Performance Standards and Appraisal Inventory. Unpublished instrument, The Ohio State University, Columbus, $\mathrm{OH}$.

4. Ladany, N. (2004). Psychotherapy supervision: What lies beneath? Psychotherapy Research, 14, 119.

5. Horbury, C., \& Wright, M. (2001). Development of a multiskilling life cycle model. HSE Contract Research Report 328/2001. HSE Books: Suffolk.

6. Glickman, G., \& Ross. (2004). Supervision and Instructional Leadership: A Development Approach (6th ed). New York: Pearson Education

7. Borders, L. D., \& Brown, L. L. (2005). The new handbook of counseling supervision. Mahwah, NJ: Lahaska Press.

8. Reichelt, S., \& Skjerve, J. (2002). Correspondence between supervisors and trainees in their perception of supervision events. Journal of Clinical Psychology, 58, 759- 772

9. Bouheni, F. B. (2013).The effects of supervision on banking performance: European evidence, International conference "Governance \& Control in Finance \& Banking: A New Paradigm for Risk \& Performance" Paris, France, April 18-19, 2013

10. Järvinen, R., U. Lehtinen and Vuorinen, I. (1996). The Change Process of Industrialisation, Electronising Service Channels and Redesigning Organization in the Financial Sector from the Productivity Viewpoint, paper presented at the 2nd International Research Workshop on Service Productivity, Madrid

11. Nickson, A. (2008). Findings of research on peer supervision in rural and remote Australia using technology. Institute for Research and Innovation in Social Services conference 2008.

12. Mason, R., \& Hayes, H. (2007). Telephone peer supervision and surviving as isolated consultant. Psychiatric Bulletin, 31, 215:217.

13. Enyedy, K. C., Arcinue, F., Puri, N. N., Carter, J. W., Goodyear, R. K., \& Getzelman, M. A. (2003). Hindering phenomena in group supervision: Implications for practice. Professional Psychology: Research \& Practice, 34, 312-317.

14. Oni, S.I. (1999). Urban transportation at State and Local Government levels, Department of Geography - University Of Lagos, Akoka-Lagos.

15. Hechanova-Alampay, R., \& Beehr, T.A. (2001). Empowerment, Span of Control, and Safety Performance in Work Teams after Workforce Reduction. Journal of Occupational Health Psychology, 6(4), 275-282.

16. Johnston, R., \& P. J. (2004). "Service Productivity: Towards understanding the relationship between operational and customer productivity,"
International Journal of Productivity and Performance Management, 53(3):201-213.

17. Courbois, J.Y.P. (2006). Training and Employees Productivity in the Workplace, American Journal of Business, 2(1): 79-86.

18. Bjorkman, M., \& Svensson, J. (2009). Power to the People: Evidence from a Randomized Field Experiment of a Community-Based Monitoring Project in Uganda. Quarterly Journal of Economics, 124:2.

19. Chen, Y. (2014). Group emotional intelligence effects on group decision-making under emergency. International Journal of Hybrid Information Technology, 7(6):189-198

20. Peck, C.P., Lyman, T., \& Rosenberg, R. (2003). Guiding Principles for Regulation and Supervision of Microfinance, Washington, DC: Consultative Group to Assist the Poor.

21. Chortareas, G., Girardone, C., Ventouri, A. (2012). Bank supervision, regulation, and efficiency: Evidence from the European Union, Journal of Financial Stability, 8, 292- 302.

22. Page, B. J., Pietrzak, D. R., \& Sutton, J. M. (2001). National survey of school counselor supervision. Counselor Education and Supervision, 41, 142150.

23. Kurosowa, M. (2006). Productivity Measurement Issues in Services Industries: Economic Policy Review, September, 23-33.

24. Dennis, A.S., \& Griffin, R.W. (2005). Human Resource Management, Boston, Houghton Mifflin Company.

25. Esia-Donkoh, K., \& Ofosu-Dwamena, E. (2014). Effects of educational supervision on professional development: perception of public basic school teachers at Winneba, GhanaBritish Journal of Education, 2(6), 63-82

26. Apenteng, J.O. (2012). Effect of supervision on staff performance in Ga South Municipal Education Directorate, A thesis submitted to the Institute of Distance Learning, Kwame Nkrumah University of Science and Technology in partial fulfillment of the requirements for degree of Commonwealth Executive Master of Business Administration, Institute of Distance Learning, Knust.

27. Hoojqan, A. R., Gharamani, J., \& Safari, S. A. (2015). Effect of educational supervision on improving teachers' performances in guidance schools of Marand, Indian Journal of Fundamental and Applied Life Sciences, 5(2), 1731-1735

28. Alhusna, T. (2001). A handbook for measuring employee performance plans with organizational goals. 